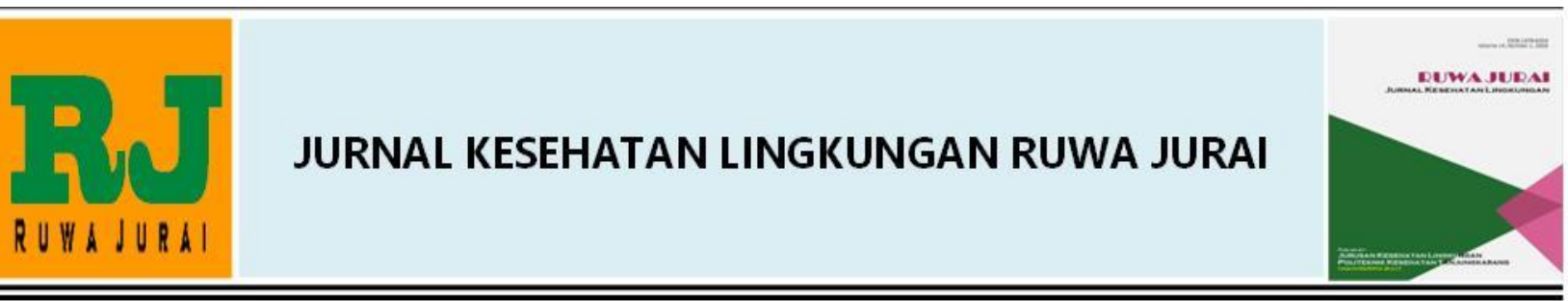

\title{
ANALISIS FAKTOR CEMARAN SUMUR TERHADAP KEJADIAN HEPATITIS A DI KECAMATAN NGADIROJO KABUPATEN PACITAN
}

\author{
Isna Wahyu Setiani ${ }^{1}$, Ferry Kriswandana ${ }^{2 *}$, Rachmaniyah ${ }^{3}$
}

${ }^{1,2,3}$ Department of Environmental Health, Poltekkes Kemenkes Surabaya.

\section{Artikel Info :}

Received 28 Juli 2020

Accepted 22 Agustus 2020

Available online 24 Agustus

2020

Editor: Prayudhy Yushananta

Key word :

Hepatitis A, dug-well construction, Escherichia coli

Kata Kunci :

Hepatitis $A$, konstruksi sumur gali, Escherichia coli

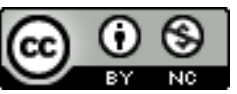

Ruwa Jurai: Jurnal

Kesehatan Lingkungan is

licensed under a Creative

Commons Attribution-

NonCommercial 4.0 International

License.

\begin{abstract}
Hepatitis $A$ is a fecal oral disease which is still a public health problem in Indonesia. The Pacitan Regency Government has determined an extraordinary event (KLB) of Hepatitis A since June 25th, 2019, there were 1,310 confirmed cases. This research aims to determine the relation between well contamination and the incidence of Hepatitis $A$. This study used a case control design by means of observation and measurement of 36 dug wells randomly selected from 18 cases and 18 controls based on inclusion criteria. The water microbiology examination was carried out at the Surabaya Health Polytechnic Laboratory with the Most Probable Number (MPN) method, and the data analysis technique used was the serial point coefficient correlation. The results suggested that all observed well water was contaminated by Escherichia coli bacteria and more than half of them did not meet the construction requirements, namely from the aspect of distance from pollutant sources, walls, lips and well floors. The analysis results suggested a relation between $E$. coli contamination and well construction $(p$-value $=0.036)$. However, it did not show a significant relation with the incidence of Hepatitis $A$ ( $p$-value $=0.514)$. Improved well construction, increased knowledge, and hygiene behavior are efforts of which must be made in managing Hepatitis $A$.
\end{abstract}

\begin{abstract}
Penyakit Hepatitis A merupakan penyakit fecal oral yang masih menjadi masalah kesehatan masyarakat di Indonesia. Pemerintah Kabupaten Pacitan telah menetapkan kejadian luar biasa (KLB) Hepatitis A sejak tanggal 25 Juni 2019, tercatat jumlah kasus sebanyak 1.310 orang. Penelitin bertujuan untuk mengetahui hubungan cemaran sumur dengan kejadian Hepatitis $A$. Penelitian menggunakan rancangan case control dengan cara pengamatan dan pengukuran terhadap 36 sumur gali yang dipilih secara acak dari 18 kasus dan 18 kontrol berdasarkan kriteria inklusi. Pemeriksaan mikrobiologi air dilakukan di Laboratorium Politeknik Kesehatan Surabaya dengan metode Most Probable Number (MPN), dan teknik analisis data yang digunakan adalah korelasi koefisien poin serial. Hasil penelitian mendapatkan bahwa seluruh air sumur yang diobservasi telah tercemar oleh bakter Escherichia coli, dan lebih dari separuhnya tidak memenuhi syarat konstruksi, yaitu dari aspek jarak dari sumber pencemar dinding, bibir dan lantai sumur. Hasil analisis menunjukkan adanya hubungan cemaran E. coli dengan konstruksi sumur ( $p$-value $=0,036$ ). Namun, tidak menunjukkan hubungan yang signifikans dengan kejadian penyakit Hepatitis $A$ ( $p$-value $=0.514)$. Perbaikan konstruksi sumur, peningkatan pengetahuan, serta perilaku hygiene merupakan upaya yang harus dilakukan dalam pengendalian penyakit Hepatitis $A$.
\end{abstract}

\footnotetext{
${ }^{*}$ Corresponding author: Ferry Kriswandana

Jl. Pucang Jajar Tengah No.56, Kertajaya, Kec. Gubeng, Kota Surabaya, Jawa Timur 60282.

Email: : ferry.kesling@gmail.com
}

\section{PENDAHULUAN}

Penyakit Hepatitis A merupakan masalah kesehatan masyarakat di negara-negara berkembang, termasuk Indonesia (Pratiwi, Soekarso, Adam, \& Setiawaty, 2017). Virus
Hepatitis A tidak dapat hidup secara bebas, melainkan harus di dalam sel makhluk hidup yang lainnya, antara lain pada manusia, hewan, tumbuhan dan juga bakteri. Penularan utama penyakit Hepatitis A melalui fecal oral yakni virus 
masuk ke dalam tubuh ketika seseorang mengonsumsi makanan atau minuman yang terkontaminasi tinja yang mengandung virus Hepatitis A.

Indonesia merupakan salah satu negara dengan prevalensi penyakit Hepatitis A yang cukup tinggi. Berdasarkan data dan infomasi Kementerian Kesehatan tahun 2014, kejadian luar biasa (KLB) Hepatitis A pernah terjadi sepanjang Tahun 2013 di berbagai provinsi. Di Provinsi Riau, tercatat jumlah kasus KLB Hepatitis A sebanyak 87 orang, Provinsi Lampung sebanyak 11 orang, Provinsi Sumatera Barat sebanyak 58 orang, Provinsi Jambi sebanyak 26 orang, Provinsi Jawa Tengah sebanyak 26 orang, dan Provinsi Jawa Timur dengan kasus tertinggi, sebanyak yaitu 287 orang.

Pemerintah Kabupaten Pacitan telah menetapkan KLB Hepatitis A sejak tanggal 25 Juni 2019. Penetapan KLB berdasarkan jumlah kasus yang semakin bertambah dan jumlahnya telah melebihi dari dua kali dari rata-rata kejadian normal (Suni, 2019). Berdasarkan data Dinas Kesehatan Kabupaten Pacitan Tahun 2019, dari hasil pemantauan yang dilakukan pada bulan Juni-Oktober 2019, didapati jumlah penderita Hepatitis A sebanyak 1.310 kasus yang tersebar di 13 wilayah kerja Puskesmas.

Hasil observasi lapangan yang dilakukan pada tanggal 22-23 Oktober 2019, musim kemarau yang terjadi di beberapa wilayah Kabupaten Pacitan berdampak pada kurangnya pasokan air bersih dan menimbulkan masalah kesehatan bagi masyarakat, salah satunya adalah Hepatitis A. Hasil pemeriksaan kualitas mikrobiologi air bersih di Puskesmas Ngadirojo mendapatkan bahwa air sumur/kubangan sungai telah tercemar bakteri Escherichia coli ( $E$. coli $>2400 / 100 \mathrm{ml}$ sampel). Untuk mengantisipasi meningkatnya kasus Hepatitis $A$, petugas kesehatan telah melakukan upaya pencegahan pada sumber air bersih warga untuk mengurangi kadar cemaran air.

Penularan Hepatitis A umumnya terjadi melalui air dan makanan yang tercemar, personal hygiene yang rendah dan kondisi sanitasi lingkungan yang buruk. Persyaratan air bersih dari sumur perlu memperhatikan kualitas air dengan memperhatikan konstruksi sumur, sumber pencemar dan cara pengolahan sebelum dikonsumsi (Apriliana, „\& Sunarko, 2017).
Kualitas air bersih yang digunakan untuk keperluan hygiene sanitasi harus sesuai persyaratan secara fisik, kimia maupun biologi. Air bersih untuk keperluan hygiene sanitasi tidak diperkenankan terdapat bakteri E. coli (Peraturan Menteri Kesehatan Republik Indonesia Nomor 32 tahun 2017, 2017).

Bakteri E. Coli merupakan kelompok bakteri Coliform yang digunakan sebagai indikator cemaran biologi (Yushananta \& Ahyanti, 2017). Semakin tinggi tingkat kontaminasi bakteri Coliform, maka semakin tinggi pula resiko kehadiran bakteri pathogen lainnya yang biasa hidup dalam kotoran manusia yang dapat menyebabkan diare, tyhpus dan Hepatitis A (Afifah, 2019).

Penderita Hepatitis A harus menjaga kebersihan diri, dan menjamin air minum terbebas dari virus Hepatitis A dengan cara memanaskan hingga mendidih (Cahyono, 2009). Minimnya pengetahuan masyarakat tentang bahaya bakteri $E$. Coli mengakibatkan kurangnya kesadaran untuk mendeteksi dan mengambil langkah pencegahan terhadap bakteri tersebut.

Penelitian bertujuan untuk menganalisis hubungan konstruksi sumur dengan cemaran air sumur warga, serta hubungan cemaran bakteri $E$. coli dengan kejadian Hepatitis A di wilayah kerja Puskesmas Ngadirojo Kabupaten Pacitan tahun 2020.

\section{METODE}

Penelitian menggunakan metode analitik observasional dengan rancangan case control, di wilayah kerja Puskesmas Ngadirojo Kabupaten Pacitan. Populasi penelitian adalah seluruh penderita Hepatitis A yang tercatat pada buku register Hepatitis A pada tahun 2019. Jumlah sampel sebanyak 36 orang $(P 1=0,8 ; P 2=0,5 ; \alpha=$ 0,$05 ; \beta=0,2$ ) yang dipilih secara acak, terdiri dari 18 orang kasus dan 18 orang sampel. Sedangkan kriteria inklusi yang ditetapkan adalah a) berdomisili tetap di wilayah kerja Puskesmas Ngadirojo; dan b) memiliki sumur sebagai sumber air bersih.

Pengumpulan data dilakukan dengan cara observasi yang berpedoman pada instrumen yang telah dikembangkan sebelumnya. Pengambilan sampel air bersih juga dilakukan untuk mengetahui kualitas biologi air bersih pada sumber air responden. Protokol penelitian 
ini telah dinyatakan layak etik oleh Komisi Etik Penelitian Kesehatan Politeknik Kesehatan Kemenkes Surabaya, melalui ethicall clearence No.EA/235/KEPK-Poltekkes_Sby/V/2020.

Metode analisis dalam penelitian ini menggunakan analisis univariat untuk menjelaskan karakteristik sumber air bersih, serta analisis bivariat untuk mengetahui hubungan variabel indendent dengan dependent menggunakan uji korelasi koefisien poin serial, mengingat data berskala ukur interval dan nominal. Hasil analisis dinyatakan berhubungan jika tingkat signifikansi atau $p$-value $<\alpha(0,05)$.

\section{HASIL}

1. Konstruksi sumur

Indikator penilaian konstruksi sumur gali mencakup penilaian jarak dengan sumber pencemar, dinding, bibir dan lantai sumur. Hasil penilaian disajikan pada Tabel 1.

Tabel 1. Konstruksi Sumur Gali

\begin{tabular}{llllll}
\hline No & Konstruksi & Baik & \multicolumn{3}{c}{ Kurang Baik } \\
& & $\mathrm{n}$ & $\%$ & $\mathrm{n}$ & $\%$ \\
\hline 1 & Jarak sumur & 11 & 30,6 & 25 & 69,4 \\
2 & Dinding sumur & 15 & 41,7 & 21 & 58,3 \\
3 & Bibir sumur & 16 & 44,4 & 20 & 55,6 \\
4 & Lantai sumur & 17 & 47,2 & 19 & 58,2 \\
\hline
\end{tabular}

Dari Tabel 1, terlihat bahwa mayoritas $(69,4 \%)$ jarak sumur gali dengan sumber pencemar tidak memenuhi syarat kesehatan, yaitu kurang dari 10 meter. Sedangkan dinding, bibir dan lantai sumur gali yang tidak memenuhi syarat, terdapat pada lebih dari separuh sumur gali yang diobservasi.
Dari keempat persyaratan konstruksi sumur gali tersebut, selanjutnya dikelompokkan menjadi dua, yaitu sumur gali yang memenuhi syarat dan tidak memenuhi syarat. Hasilnya, sebanyak $55,6 \%$ sumur gali milik rersponden tidak memenuhi syarat kesehatan.

Tabel 2. Kualitas Biologi Air Sumur Gali

\begin{tabular}{|c|c|c|c|c|c|c|c|}
\hline No & Identitas & Hasil & Ket & No & Identitas & Hasil & Ket \\
\hline 1 & Sumur 1 & 26 & TMS & 19 & Sumur 19 & 27 & TMS \\
\hline 2 & Sumur 2 & 40 & TMS & 20 & Sumur 20 & 21 & TMS \\
\hline 3 & Sumur 3 & 30 & TMS & 21 & Sumur 21 & 60 & TMS \\
\hline 4 & Sumur 4 & 26 & TMS & 22 & Sumur 22 & 27 & TMS \\
\hline 5 & Sumur 5 & 21 & TMS & 23 & Sumur 23 & 21 & TMS \\
\hline 6 & Sumur 6 & 49 & TMS & 24 & Sumur 24 & 26 & TMS \\
\hline 7 & Sumur 7 & 27 & TMS & 25 & Sumur 25 & 14 & TMS \\
\hline 8 & Sumur 8 & 21 & TMS & 26 & Sumur 26 & 9 & TMS \\
\hline 9 & Sumur 9 & 34 & TMS & 27 & Sumur 27 & 14 & TMS \\
\hline 10 & Sumur 10 & 17 & TMS & 28 & Sumur 28 & 13 & TMS \\
\hline 11 & Sumur 11 & 21 & TMS & 29 & Sumur 29 & 26 & TMS \\
\hline 12 & Sumur 12 & 60 & TMS & 30 & Sumur 30 & 33 & TMS \\
\hline 13 & Sumur 13 & 70 & TMS & 31 & Sumur 31 & 50 & TMS \\
\hline 14 & Sumur 14 & 27 & TMS & 32 & Sumur 32 & 26 & TMS \\
\hline 15 & Sumur 15 & 26 & TMS & 33 & Sumur 33 & 33 & TMS \\
\hline 16 & Sumur 16 & 21 & TMS & 34 & Sumur 34 & 90 & TMS \\
\hline 17 & Sumur 17 & 21 & TMS & 35 & Sumur 35 & 50 & TMS \\
\hline 18 & Sumur 18 & 23 & TMS & 36 & Sumur 36 & 21 & TMS \\
\hline
\end{tabular}

Ket : TMS = Tidak Memenuhi Syarat 


\section{Kualitas Biologi Air Sumur}

Pada penelitian ini dilakukan pengambilan sampel untuk pemeriksaan kualitas biologi air sumur, yang dinilai berdasarkan jumlah bakteri E. coli tiap $100 \mathrm{ml}$ sampel. Hasil pemeriksaan kualitas biologi disajikan pada Tabel 2 .

Pada Tabel 2 terlihat bahwa seluruh air sumur gali yang diperiksa tidak memenuhi syarat kesehatan atau tercemar oleh tinja manusia. Pada air bersih, tidak diperbolehkan terdapat bakteri E. coli (Peraturan Menteri Kesehatan Republik Indonesia Nomor 32 tahun 2017, 2017).
3. Hubungan Konstruksi dan Cemaran Air Sumur

Hasil uji korelasi koefisien poin biserial didapatan nilai hasil $p$-value $=0,036$, menunjukkan adanya hubungan konstruksi sumur dengan cemaran air sumur. Gambar 1 menunjukkan pola hubungan kedua variabel, dimana angka $E$. coli yang tinggi didominasi oleh konstruksi sumur yang tidak memenuhi syarat.

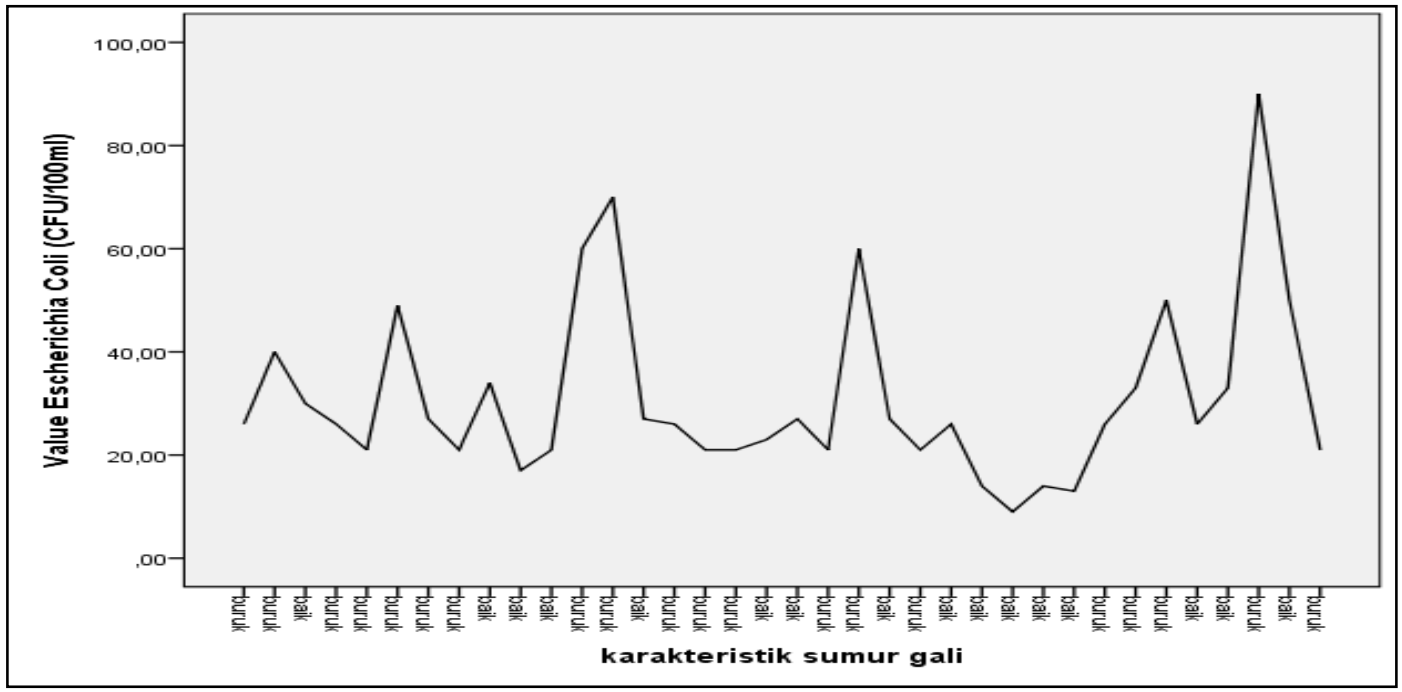

Gambar 1. Hubungan Konstrusi dan Cemaran Air Sumur

\section{PEMBAHASAN}

1. Konstruksi Sumur

Hasil penelitian mendapatkan bahwa sebanyak $69,4 \%$ sumur memiliki jarak kurang dari 10 meter, sehingga berisiko terjadinya pencemaran dari septic tank. Syarat jarak 10 meter sumur dan tanki septic tank disebabkan kemampuan bertahan hidup di lingkungan dari bakteri $E$. coli selama tiga hari dan kemampuan bergerak mengikuti aliran air dalam tanah sekitar 3 meter/hari. Sehingga jarak ideal antara sumber air dengan septic tank minimal 10 meter (Khomariyatika \& Pawenang, 2011; Muchlis, Thamrin, \& Siregar, 2017; Sangadjisowohy, 2019; Sapulete, 2013; Yushananta \& Usman, 2018).

Selain resapan septic tank, sumber pencemar utama lainnya adalah air limbah domestik dan kandang ternak. Sebagian besar rumah tangga mengalihfungsikan sebagian halamannya untuk kandang ternak. Sedangkan aliran air limbah rumah tangga dialirkan ke permukaan tanah secara terbuka, dan berdekatan dengan kandang ternak. Air limbah akan bercampur dengan kotoran ternak, selanjutnya akan mencemari air sumur sebagai sumber air bersih (Yushananta \& Usman, 2018; Yustiani, Hasbiah, \& Fuad, 2019).

Dinding sumur adalah lapisan kedap air yang membatasi lubang sumur dan dinding tanah dengan kedalaman 3 meter dari permukaan tanah. Dinding sumur gali harus terbuat dari bahan kedap air, biasanya menggunakan semen, agar tidak terjadi rembesan air permukaan. Pada kedalaman 3 meter, lapisan tanah sudah semakin rapat sebagai media filterisasi alamiah, sehingga mengurangi kandungan bakteri dari air rembesan, dan air (Irfandi, Ashar, \& Chahaya, 2014). 


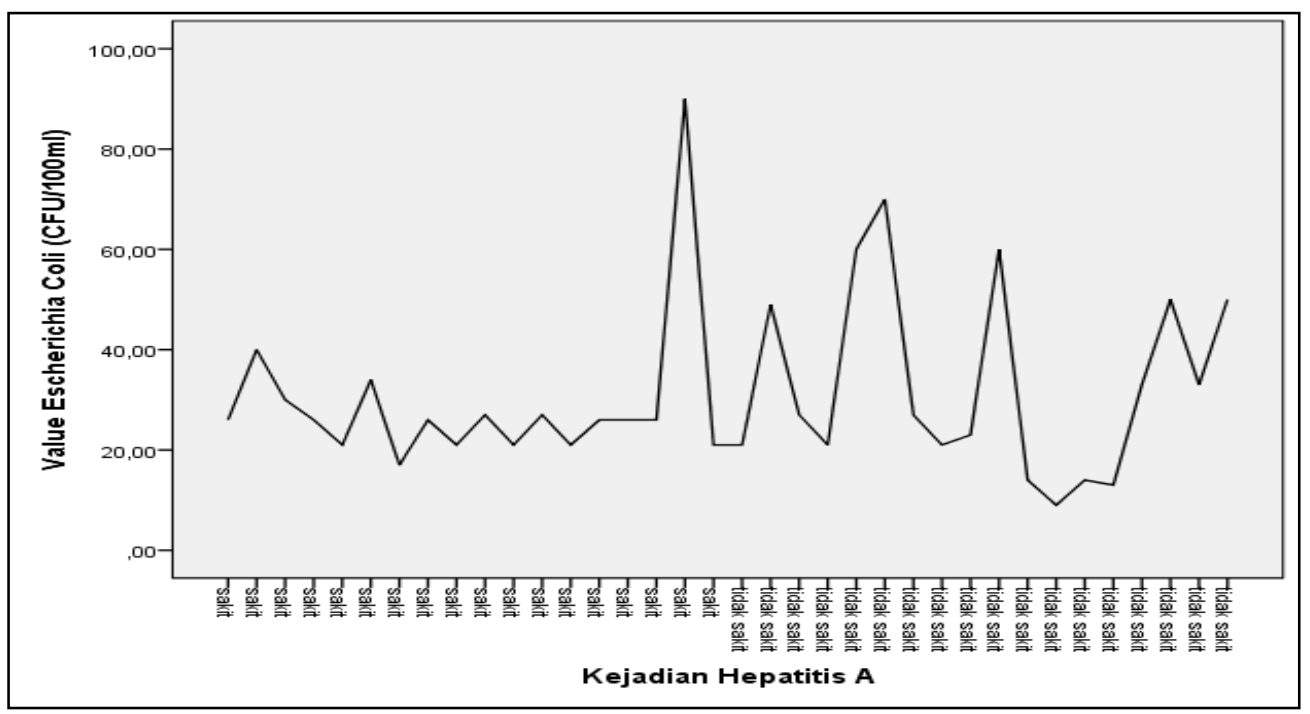

Gambar 2. Hubungan cemaran E. coli dan kejadian Hepatitis A

Hasil penelitian mendapatkan sebanyak $58,3 \%$ sumur gali memiliki dinding yang tidak memenuhi syarat kesehatan. Sebagian dinding sumur tidak dilapisi lapisan kedap air, lapisan pecah atau retak, atau ketinggiannya kurang dari 3 meter. Sumber air bersih dengan dinding kedap air kurang dari 3 meter akan memperbesar kemungkinan terkontaminasi (Hasnawi et al., 2012; Pratiwi et al., 2017). Kondisi dinding sumur yang tidak memenuhi syarat, berhubungan dengan kandungan bakteri $E$. coli pada air sumur (Adam, Sumampouw, \& Pinontoan, 2019; Apriliana et al., 2017; Hasnawi et al., 2012; Sangadjisowohy, 2019; Sharon, Woodford, \& Oksfriani, 2018).

Bibir sumur gali merupakan dinding sumur yang berada di permukaan tanah, kedap air, dengan ketinggian minimal $70 \mathrm{~cm}$. Selain untuk keamanan, bibir sumur untuk mencegah masuknya air buangan ke dalam sumur. Hasil penelitian mendapatkan $55,6 \%$ sumur gali yang tidak memiliki bibir sumur sesuai dengan persyaratan kesehatan. Sumur gali dengan konstruksi bibir sumur yang tidak memenuhi syarat berhubungan dengan peningkatan coliform air sumur (Hasnawi et al., 2012; Khomariyatika \& Pawenang, 2011; Sangadjisowohy, 2019; Yustiani et al., 2019). Konstruksi sumur gali yang tidak memenuhi syarat berkaitan dengan pengetahuan (Putri, 2017; Rahadi, 2019; Yushananta \& Usman, 2018) dan kemampuan sosial ekonomi masyarakat (Yustiani et al., 2019).
Lantai sumur adalah lantai kedap air yang mengelilingi sumur dengan jarak sekitar 1 meter dari bibir sumur, dan diakhiri dengan saluran air limbah pada bagian pembuangnnya. Hasil penelitian mendapatkan sebanyak $52,8 \%$ sumur gali tidak memeiliki lantai sumur yang memenuhi syarat.

Lantai sumur bertujuan untuk menghindari masuknya air kotor ke dalam sumur. Konstruksi lantai yang tidak memenuhi syarat memberi kontribusi yang besar terhadap pencemaran air sumur (Hasnawi et al., 2012; Putri, 2017), dan berdampak pada kualitas biologi air (Apriliana et al., 2017; Khomariyatika \& Pawenang, 2011; Sapulete, 2013; Sharon et al., 2018; Yustiani et al., 2019).

\section{Hubungan Konstruksi Sumur dengan Cemaran Air Sumur}

Hasil penelitian menunjukkan adanya hubungan konstruksi sumur dengan cemaran air sumur ( $p$-value $=0,036$ ). Konstruksi yang tidak baik meliputi jarak sumur dengan sumber pencemar kurang dari 10 meter, serta dinding, bibir dan lantai sumur yang tidak kedap air. Sumber pencemar dimaksud adalah resapan septik tank, kandang ternak, dan saluran pembuangan air limbah tidak kedap air.

Konstruksi sumur gali yang tidak memenuhi syarat akan berdampak pada penurunan kualitas biologi air. Jarak sumur yang kurang dari 10 meter, memungkinkan masuknya mikroba pathogen dari sumber pencemar (Hasnawi et al., 2012; Ihsan, Sudarno, \& Oktiawan, 2017; 
Khomariyatika \& Pawenang, 2011; Sapulete, 2013; Sharon et al., 2018; Yustiani et al., 2019). Kondisi ini semakin diperparah dengan konstruksi dinding, bibir dan lantai sumur yang tidak kedap air, sehingga meningkatkan risiko cemaran pada air sumur (Apriliana et al., 2017; Hasnawi et al., 2012; Irfandi et al., 2014; Khomariyatika \& Pawenang, 2011; Sapulete, 2013; Sharon et al., 2018; Yustiani et al., 2019).

Meskipun telah dilakukan klorinasi oleh petugas kesehatan pada sumur penderita Hepatitis A, namun hasil pemeriksaan mikrobiologis masih menunjukkan kualitas air yang belum memenuhi persyaratan. Diduga, pemberian kaporit dengan dosis $100 \mathrm{mg} / \mathrm{m}^{3}$ yang diberikan sekali seminggu, belum cukup mampu untuk membunuh bakteri E. coli yang terdapat pada air sumur. Sehingga perlu pengujian untuk penetapan dosis kaporit yang efektif, terutama memastikan air dikonsumsi setelah proses pendidihan.

Konstruksi sumber air yang tidak memnuhi syarat, berkaitan dengan pengetahuan masyarakat tentang risiko pencemaran terhadap penularan penyakit (Al Khakim, 2017; Putri, 2017; Rahadi, 2019; Sumarni \& Susanna, 2014; Yushananta, Ahyanti, \& Hasan, 2018; Yushananta \& Usman, 2018). Sehingga perlu upaya untuk meningkatkan pengetahuan masyarakat tentang pengelolaan sumber air bersih, baik pada aspek konstruksi, perawatan, serta hubungan air dengan penularan penyakit. Kehadiran bakteri Coliform dalam jumlah tertentu di dalam substrat ataupun benda, misalnya air dan bahan makanan, juga merupakan indikator kehadiran bakteri penyakit lainnya (Yushananta \& Ahyanti, 2017).

\section{Hubungan Cemaran E. coli dengan Kejadian Hepatitis A}

Pada penelitian ini, hasil uji statistik tidak menunjukkan hubungan yang bermakna antara cemaran E. coli dengan kejadian Hepatitis A ( $p$ value $=0,514$ ). Tidak terdapatnya hubungan, disebabkan homogenitas data dari hasil pemeriksaan kualitas biologi air sumur. Berbeda dengan (Ropiah, Hernawan, \& Selviana, 2016), yang menyatakan adanya hubungan yang signifikans antara kualitas mikrobiologi air bersih dengan kejadian Hepatitis A ( $p$-value $=0,045)$, dan kelompok kasus dengan kualitas mikrobiologi air bersih berisiko 2,752 kali mengalami kejadian Hepatitis A $(O R=2,752$; 95\% Cl = 1,117-6,781).

Hepatitis A merupakan penyakit menular fecal oral yang sering menimbulkan KLB. Penularan penyakit melalui makanan atau air yang tercemar virus Hepatitis A. Penyebaran penyakit Hepatitis A tergolong mudah pada kondisi tidak terpenuhinya sistem sanitasi lingkungan yang tidak memenuhi syarat kesehatan, yaitu tersedianya air bersih dengan kualitas dan kuantitas yang baik, serta konstruksi sumber air bersih yang memenuhi syarat kesehatan. Mengintervensi kedua variabel tersebut, serta meningkatkan perilaku hygiene, akan menurunkan kejadian Hepatitis A (AI Khakim, 2017; Rahadi, 2019). Peran lingkungan dalam penularan Hepatitis A melalui penggunaan air bersih yang tercemar (Syahrul, Mubawadi, Mirasa, \& Agung, 2018).

Keberadaan bakteri $E$. coli secara tidak langsung menunjukkan peluang adanya mikroorganisme lain di dalam air, seperti Salmonella spp maupun virus Hepatitis A (Adam et al., 2019; Syahrul et al., 2018; Yushananta \& Ahyanti, 2017). Pemeriksaan E. coli pada air bersih mengikuti konsep fail safe, artinya, bila air positif tercemar tinja maka diasumsikan di dalam air juga terdapat kuman patogen lainnya (Sumarni \& Susanna, 2014).

\section{SIMPULAN}

Hasil penelitian mendapatkan bahwa mayoritas sumur gali memiliki jarak kurang dari 10 meter dari sumber pencemar, terutama resapan septic tank dan kandang ternak. Sedangkan dinding, bibir dan lantai sumur gali yang tidak memenuhi syarat, ditemukan pada lebih dari separuh sumur gali yang diobservasi. Berdasarkan hasil pemeriksaan mikrobiologis, seluruh sumur dinyatakan tercemar oleh bakteri E. coli. Cemaran E. coli berkaitan dengan konstruksi sumur yang tidak memenuhi syarat kesehatan ( $p$-value $=0,036$ ).

Selain perbaikan konstruksi sarana air bersih, perlu upaya peningkatan pengetahuan masyarakat tentang pengelolaan sumber air bersih, baik pada aspek konstruksi, perawatan, dan hubungan air dengan penularan penyakit, serta meningkatkan perilaku hygiene sebagai upaya pengendalian penyakit Hepatitis A. 
Pemberian disinfektan dengan dosis efektif pada air sumur gali secara rutin menjadi prioritas jangka pendek pada masa KLB Hepatitis A.

\section{DAFTAR PUSTAKA}

Adam, M., Sumampouw, O. J., \& Pinontoan, O. R. (2019). Kandungan Coliform dan Escherichia Coli Pada Sumber Air Bersih Di Desa Kumelembuai dan Kumelembuai Dua Kabupaten Minahasa Selatan. Juornal PHWB, 1(1), 36-44.

Afifah, F. (2019). Uji Bakteriologis Coliform Dan Escherichia Coli Pada Air Tanah Bebas. https://doi.org/10.31227/osf.io/fp9kr

Al Khakim, A. R. (2017). Dinamika Bakteri Coliform Disebabkan Oleh Tekanan, Kekeruhan dan Sisa Chlor di Kota Surabaya (FKM Universitas Airlangga). Retrieved from http://repository.its.ac.id/47732/

Apriliana, C., . D., \& Sunarko, B. (2017). Pengaruh Konstruksi Sumur Gali Terhadap Kualitas Bakteriologis Air Bersih di Puskesmas Tekung Kabupaten Lumajang Tahun 2017. GEMA LINGKUNGAN KESEHATAN, 15(3). https://doi.org/10.36568/kesling.v15i3.695

Cahyono, S. B. (2009). Hepatitis A (Cegah penularannya). Yogyakarta: Kanisius.

Hasnawi, H., Kesehatan, J., Kesehatan, I.-I., Keolahragaan, D., Heriyani, A., Pengaruh, $\mathrm{H}$. 2012, ... Masyarakat, K. (2012). Pengaruh Konstruksi Sumur Terhadap Kandungan Bakteri Eschercia Coli Pada Air Sumur Gali di Desa Dopalak Kecamatan Paleleh Kabupaten Buol. In Public Health Journal (Vol. 1). State University of Gorontalo.

Ihsan, M. F., Sudarno, S., \& Oktiawan, W. (2017). Kajian Kualitas Air Sumur Gali untuk Wilayah Pedalangan yang Mempunyai IPAL Komunal. Retrieved August 20, 2020, from Jurnal Teknik Lingkungan

Irfandi, A., Ashar, T., \& Chahaya, I. (2014). Analisis Kandungan Kadmium (Cd) Dan Timbal (Pb) Pada Air Sumur Gali Penduduk di Sekitar Industri Daur Ulang Aki Dan Gangguan Kesehatan Pada Masyarakat Desa Bandar Khalipah Kabupaten Deli Serdang Tahun 2013. In Lingkungan dan Keselamatan Kerja (Vol. 3). University of North Sumatra.

Khomariyatika, T., \& Pawenang, T. E. (2011). Kualitas Bakteriologis Air Sumur Gali. Kesmas, Jurnal Kesehatan Masyarakat, 7(1), 63-72. https://doi.org/10.15294/kemas.v7i1.1794 Muchlis, M., Thamrin, T., \& Siregar, S. H. (2017).
Analisis Faktor yang Mempengaruhi Jumlah Bakteri Escherichia coli pada Sumur Gali Penderita Diare di Kelurahan Sidomulyo Barat Kota Pekanbaru. Dinamika Lingkungan Indonesia, 4(1), 18. https://doi.org/10.31258/dli.4.1.p.18-28

Peraturan Menteri Kesehatan Republik Indonesia Nomor 32 tahun 2017. Standar Baku Mutu Kesehatan Lingkungan dan Persyaratan Kesehatan Air Untuk Keperluan Higiene Sanitasi, Kolam Renang, Solus Per Aqua, dan Pemandian Umum. , Peraturan Menteri kesehatan Republik Indonesia § (2017).

Pratiwi, E., Soekarso, T., Adam, K., \& Setiawaty, V. (2017). Identifikasi Virus Hepatitis A pada Sindrom Penyakit Kuning Akut di Beberapa Provinsi di Indonesia Tahun 2013. Global Medical \& Health Communication (GMHC), 5(3), 199. https://doi.org/10.29313/gmhc.v5i3.2386

Putri, E. S. (2017). Analisis Hubungan Pengetahuan, Sikap dan Kontruksi Sumur Gali Terhadap Kualitas Sumur Gali. Prosiding Seminar Nasional USM, 1(1), 481-486.

Rahadi, R. (2019). Hubungan Antara Faktor Lingkungan Dan Perilaku Dengan Kejadian Hepatitis A Pada Masyarat Bantaran Sungai Bengawan Solo Kota Surakarta. Retrieved from http://repository.setiabudi.ac.id/3366/1/INTISAR I DAN ABSTRACT JURNAL RYAN.pdf

Ropiah, R., Hernawan, A. D., \& Selviana, N. 1122028801. (2016). Faktor Lingkungan Dan Perilaku Yang Berhubungan Dengan Kejadian Hepatitis A Di Kecamatan Sintang Kabupaten Sintang (Universitas Muhamadyah Pontianak).

Sangadjisowohy, D. (2019). Uji Kandungan Bakteriologi Pada Air Sumur Gali Ditinjau Dari Konstruksi Sumur di Kelurahan Sangaji Kecamatan Ternate Utara. PROMOTIF: Jurnal Kesehatan Masyarakat, 9(1), 20-27. https://doi.org/http://dx.doi.org/10.31934/prom otif.v9i1.577

Sapulete, M. R. (2013). Hubungan Antara Jarak Septic Tank Ke Sumur Gali dan Kandungan Escherichia Coli Dalam Air Sumur Gali di Kelurahan Tuminting Kecamatan Tuminting Kota Manado. JURNAL BIOMEDIK (JBM), 2(3). https://doi.org/10.35790/jbm.2.3.2010.1197

Sharon, T. L., Woodford, J. B., \& Oksfriani, S. J. (2018). Hubungan Antara Faktor Konstruksi Dan Jarak Sumur Gali Terhadap Sumber Pencemar Dengan Total Coliform Air Sumur Gali di Kelurahan Motto Kecamatan Lembeh Utara. In Jurnal KESMAS (Vol. 7). Retrieved from https://ejournal.unsrat.ac.id/index.php/kesmas/ 
article/view/23160

Sumarni, I., \& Susanna, D. (2014). Kondisi Kesehatan Lingkungan Pesantren dan Perilaku Hidup Bersih dan Sehat Siswa dengan Kejadian Hepatitis. Kesmas: National Public Health Journal, 9(2), 179. https://doi.org/10.21109/kesmas.v9i2.515

Suni, N. S. P. (2019). Tantangan dalam penanggulangan kejadian luar biasa (klb) penyakit hepatitis a di pacitan. Pusat Penelitian Badan Keahlian DPR RI, 11(14), 13-18.

Syahrul, F. B. H., Mubawadi, F., Mirasa, T., \& Agung, Y. (2018). Analisa Kejadian Luar Biasa Hepatitis A Di SMA X Kabupaten Lamongan Tahun 2018. Jurnal Berkala Epidemiologi, 6(2), 112-121.

Yushananta, P., \& Ahyanti, M. (2017). Risiko Fotoreaktivasi terhadap Kualitas Mikrobiologi Air Minum Isi Ulang. Jurnal Kesehatan, 8(2), 212. https://doi.org/10.26630/jk.v8i2.482

Yushananta, P., Ahyanti, M., \& Hasan, A. (2018).
Sanitasi Total Berbasis Masyarakat di Desa Muara Putih Kecamatan Natar Kabupaten Pesawaran. Sakai Sambayan Jurnal Pengabdian Kepada Masyarakat, 2(2), 76. https://doi.org/10.23960/jss.v2i2.79

Yushananta, P., \& Usman, S. (2018). The Incidence of Diarrhea in Babies Affected through the Cleanliness of Eating Utensils and Hands. Journal of Medical Science And Clinical Research, 6(9). https://doi.org/10.18535/jmscr/v6i9.137

Yustiani, Y. M., Hasbiah, A. W., \& Fuad, R. (2019). Pengaruh Kondisi Fisik Dan Jarak Sumur Gali Dengan Peternakan Sapi Terhadap Kandungan Bakteri Coliform Air Sumur Gali di Desa Sukajaya Kecamatan Lembang Kabupaten Bandung Barat. Journal of Community Based Environmental Engineering and Management, 1(1), 19. https://doi.org/10.23969/jcbeem.v1i1.1367 